\title{
Protestant Reformation and Albanian Nationalism
}

\author{
Ylli H. Doci \\ European University of Tirana, Albania
}

doi: 10.19044/esj.2017.v13n19p117 URL:http://dx.doi.org/10.19044/esj.2017.v13n19p117

\begin{abstract}
The relationship of the Protestant Reformation with Nationalism is understandable if one can appreciate the nature of the general emancipation from the authority as understood during the Middle Ages to the subjectively defined authority that the Reformation brought forth. The connection of the emancipating influence of the Reformation with the Albanian National Awakening is made more clear if one understands not only the thought patterns typically associated with the Reformation, but also some historical dimensions of the Albanian language and education. Therefore, we propose here the thesis that the influence of the Protestant Reformation is discernable also in the history of Albanian Nationalism.
\end{abstract}

Keywords: Reformation, protestantism, modernity, nationalism, authority, education

\section{Introduction}

Crane Brinton, the Harvard professor of history wrote: "The humanists were by no means the major architects of the modern world, nor the makers of the modern mind. Insofar as these two centuries [1450-1650] went to make us what we are, by far the most important makers were the Protestants, the rationalists, and the scientists" (Brinton 1963, 53). Without fear of exaggeration we can say that almost every aspect of the modern life is a direct result of a development of the change which came about beginning with the Protestant Reformation in 1517 at the heart of the European society.

The reason why this reformation is in the center of all of the modern developments is because it consists in the general liberation from an understanding of authority developed during the Middle Ages along the lines of the dogmatic Church authorities. The new understanding of authority as viewed from the subjective side of the individual, affirming the importance of protecting freedom of conscience, is established in the social and political realm with the Reformation. In order to understand the shift in the European culture one needs to understand the paradigm shift of Martin Luther in the context of his time. The way this shift is related to the preceding humanism 
of 1400's, the rationalism of the 1600's or Enlightenment that followed, will be the understanding of the key which the Reformation represents in the intellectual history of the beginning of the modern era.

\section{Reformation and authority}

The beginning of the close relationship of the papal power and the political leadership in the area that is considered Western Europe, is associated with crowning of Charlemagne (768-814) by Pope Leo III on Christmas day of AD 800 calling the king of Franks “Augustus... Emperor of the Romans” (Harrison and Sullivan 1980, One:199). The later popes considered this event as a precedent for their right to determine the leaders of the Christian peoples and the right to judge their behavior. At the same time, with the Carolingian period there also started a rich tradition of discussions and formulations of the vision for a Western Civilization in the political, social and religious realms which provided the fertile ground of the ideas of the Reformation (Harrison and Sullivan 1980, One:2004).

The Reformation which started 500 years ago, with Martin Luther's 95 thesis in 1517, was the "eye of the storm" or the point where the "transforming tornado" touched the Middle Ages, making way for the modern world which today is a worldwide phenomenon. The Renaissance, Reformation, Rationalism, Enlightenment, Romanticism and other influences which would eventually shape the modern mentality, make up the integrated power of this "tornado" which would move history forward through political and social upheavals like the French revolution with ever widening consequences.

In order to understand the Lutheran reformation, one needs to understand the social context of that time which for more than 1000 years was permeated by the Christian consensus influencing every sphere of life and every institution. The Catholic Church, and the Pope in particular, consisted in the most prominent authority. Erasmus of Rotterdam, the humanist of that period, criticized harshly the pope of his time (Reid 1995, 2:191), but, nevertheless he remained a catholic till the end of his life because he didn't have as much concern about doctrinal issues as about general moral principles. Generally speaking, whatever grievances and criticism Christians of that time had against the Church, they didn't see on what basis could they stand to contradict the Pope, who was considered the vicar of Christ. How could a Christian raise up against the vicar of Christ? Luther was a conscientious Catholic as well and did not imagine he was going against the Pope when he decided to stand for what he believed to be the truth of the Bible against what he believed to be distortions of the teachings of Christ. 
Luther had arrived at a certain Biblical understanding about the nature of human salvation from sin and death consisting in the crux of the gospel the good news, when he wrote: “... as the result of becoming and being righteous, we do righteous acts. First the person must be changed, then the works. First Abel is acceptable, then his offerings (Sheldon 1994, 3:55). Nevertheless, he didn't doubt whether this same understanding was also the understanding of the Pope (Sheldon 1994, 3:61). On the contrary, he wrote to the Pope Leo X on 30 May 1518, declaring his sincere intentions and devotion expressing readiness to obey the Pope's decision with these words: “... prostrate I present myself at thy feet, with all that I am and all that I possess. ... Thy voice will I acknowledge as the voice of Christ” (Sheldon 1994, 3:64).

In the January of 1521, in that first year of the "divorce" from the pope, Luther was called to Worms and knowing how the heretics were treated before, Luther was ready to die when he wrote:

"...my life is of small consequence. The question of hazard or safety is not to be entertained; let us rather take heed lest we leave the gospel which we have embraced to be the sport of the wicked, and give our adversaries occasion boastfully to insinuate against us that we dare not confess what we have taught, and fear to shed our blood in its behalf. ... Though they should kindle a fire all the way from Wittenberg to Worms, the flames of which should reach to heaven, I would still appear before them in the name of the Lord, ... confessing the Lord Jesus Christ” (Sheldon 1994, 3:80-81).

When Luther arrived at this court in April of that year, he had to stand before the threat of total destruction. But because of his convictions for the truth, his understanding of the sacredness of personal convictions, his faith in the sovereignty of God before all other powers, Luther declared boldly with the words of a modern man: "Unless, therefore, I am convinced by the testimony of Scripture, or by clear reasoning, unless I am persuaded by means of the passages I have quoted, and unless my conscience is thus bound by the Word of God, I cannot and will not retract; for it is unsafe and injurious to act against one's conscience. Here I stand, I can do no other: May God help me! Amen” (Sheldon 1994, 3:82).

The issue of the ultimate authority therefore was one of the main issues that came up with Luther's stance. The understanding of this issue at that time is expressed by one of the historians in this way: "The [Roman] Catholic faith rests upon a single indivisible article; namely, the authority of the infallible Church" (Sheldon 1994, 3:2). For the people of that time the authority of the Church and Pope was absolute but Luther, although he was a son of his times, he understood from the Bible the direct connection of every person with the enlightening WORD (Bible, John 1:9) without any 
other mediation. Luther thus emphasized the personal responsibility of every person based on the authority of the Bible alone according to one's own convictions as to what it says.

The reason why we should appreciate the Biblical aspect of the stance of the Reformation against the Pope is because the reformers were primarily concerned with spiritual freedom at a time when religion was of great importance for the cohesion of the whole culture. The ideological cohesion of the Middle Ages explains the effectiveness of the explosive power of the Reformation which challenged and eventually moved away from the center of the European life the authority of the pope inaugurating the authority of conscientious democracy in the public square. The conclusion of a text of history is: "Most historians agree that the breakup of the all-powerful medieval Church was probably the most significant factor in bringing the Middle Ages to an end and that the Reformation was, therefore, of major importance in the rise of modern Western Civilization” (Harrison and Sullivan 1980, One:369).

\section{Connection of Reformation and Nationalism:}

If we arrive at the conclusion that Reformation was key to the impregnation of the modern world with the mentality of freedom of conscience, critical thinking, and social equality, it is easier then to discern also the important influence Reformation had on the development of nationalisms (Harrison and Sullivan 1980, One:369). The issue of definition of "nation" and the genesis of "nations," as well as the cultural and political dimensions of nationalism is a long and complicated discussion (Hutchinson and Smith 1994, 4) but, for our purposes here, we can say that there is no doubt about the central role of modernity, hence the role of Protestant Reformation in that connection, in the appearance of modern nationalisms.

The medieval church until the time of Luther was not a national church. The result of reformation is seen in the forming of the Calvinist churches that were national churches (Swiss, Dutch, German, Scottish, Anglican) and are in stark contrast with the medieval church. The influence of Protestantism in the formation of nations cannot be denied even though this was not an intentional goal in itself. The first goal of the Protestants is related to the Biblical mission of spreading the gospel of salvation by faith and not by works of religion. Understanding then this central characteristic of the gospel as news and containing propositional content, it is easy to see the importance of communication in the heart language of people who form a language group together hence contributing indirectly to their consolidation of their belonging together. This is how we also should understand the contribution of Luther's translation of the Bible in German which served not only to communicate the gospel as a religious preoccupation but at the same 
time and without contradiction with this prior goal, it served as a contribution for the German culture and consolidation of the German nation.

With regard to the characteristics of nationalism, two of the distinguished scholars of the subject, say in their book: “... the founding fathers - Rousseau, Herder, Fichte, Korais, and Mazzini - ... an... most subsequent nationalists [believed that] the movement brought together the vital aspirations of the modern world: for autonomy and self-government, for unity and autarchy, and for authentic identity” (Hutchinson and Smith 1994, 4). It is this ideological understanding, which implies the freedom brought about by the Protestant Reformation as the main part of the aspirations of the modern world, that, I argue, displays the important contribution in the appearing of nationalism.

Another sign of the importance of the Reformation in the appearance of nationalism can be gleaned from the question and its answer that Anthony D. Smith presents us with: "But why did nations and nationalism first emerge in Western Europe? The answer lies not in the rise of capitalism or the modern centralized state, nor the role of political geography emphasized by Hugh Seton-Watson, ... but in the influence of religion, and specifically of Christianity. The nation, according to Hastings, is a Christian phenomenon... “ (Guibernau and Hutchinson 2001, 15).

The period of great social movements that started after the Enlightenment of the XVIII and the French Revolution, which is the time of the formation of most modern nations, is accompanied also by a wave of awakenings and expansion of Protestantism and especially Evangelicalism. This expansion is noted by historians as "The Great Awakening” around 1750's, with George Whitfield and the Wesley brothers, which lasted for about 40 years. A second similar wave started around 1800's with Charles Finney when Evangelical international missions also were intensified. According to the historian Kenneth Latourette, it seems that Protestantism experienced a great expansion during this time until the middle of the $\mathrm{XX}$ century when it appears to have surpassed the extent of Orthodox Christianity and was present in all the areas where Catholic Christianity was present although less numerous (Latourette 1975, 2:1018).

Another collection of writings on nationalism confirms the same general conviction of the connection of nationalism and modernity, which again should be seen in close connection with the influence of Protestantism or ideas related to it. In this analysis of the different views about nationalism and the time of its appearance it is concluded that there are two "... contrasting calendars: modernists date their formation to the rise of modernity, in whatever form the latter is defined; perennialists see them as enduring... even millennial phenomena, certainly predating modernity. Modernism remains one of the few postulates overwhelmingly embraced by 
most scholars, in itself a rare achievement” (Leoussi and Grosby 2007, 18). It is clear that just because we say "modernist" in relation to the time of the appearance of nations we cannot assume agreement for everything but minimally “... if the modernists are right there can be neither nations nor nationalism in pre-modern eras” (Smith 1991, 44).

Although Adrian Hastings is taken as an example of a perennialist (Ozkirimli 2010, 58), he is careful to differentiate "nationalism" as an ideology that he cannot consider possible before modernity. The main thesis of Hastings is:

"modern nations can only grow out of certain ethnicities, under the impact of the development of a vernacular and the pressures of the state. ...The defining origin of the nation, Hasting argues, like that of every other great reality of modern Western experience, needs to be located in an age of a good deal further back than most modernist historians feel safe to handle, that of the shaping of medieval society” (Ozkirimli 2010, 59).

This thesis seems to support even better the claim of the importance of Protestantism as carrier of modernity in its influence related to nations and nationalism. This is so also because Hasting's thesis considers the transition of an ethnicity into nation to take place when the specific language moves from the oral phase into the use of written language, to the point that it is used regularly for producing a literature, and especially for the translation of the Bible (Hastings 1997, 11-12).

Protestant Reformation started with Luther who eventually emphasized the need for the education in the language of the people so they could read the bible for themselves and this focus on the Bible, indirectly consolidated the best basis for the development of the nationalist ideals which is the development of national school education. Although the idea of the nation had started to be discerned in the emerging of some European powers, such as England, Germany, France, only with the reformation of the church and the shift in the cultural life of the European life in the form of different responses to the influence of Reformation, do we see the national idea and the power of national education in consolidating the nations.

This is where the case of Albania also is relevant and we can see the role of Protestantism and the Albanian Evangelicals as analog to the role of Luther in his nation.

\section{Reformation and Albania}

It is important to see the connections between the Evangelical Protestant waves of expansion through the preaching of the message of the Bible and the international changes that we see influenced by the French Revolution. Such seemingly separate forces around the same time created a climate where nationalism was spreading like a virus. It is therefore 
justifiable to talk like many do about this period as if it was a natural phenomenon, as if the "period of national renaissance" could be the period of a good harvest. Nevertheless, it is important to emphasize that in spite of the trends and waves of social changes with their influences from the economic factors or political forces, the role of ideas, and in our case the role of the ideas related to the Protestant reformation, cannot be ignored. As Crane Brinton writes:

“... in human history, there are no important facts unrelated to ideas, no important ideas unrelated to facts. ... No intellectual historian need debate whether ideas or interests move mend in their relations in society, nor which comes first. Without both gasoline and spark, no working gasoline-powered internal-combustion engine; without both ideas and interests (or appetites, or drives, or material factors) no working human society, and no human history" (Brinton 1963, 12).

It is obvious that during the period we call "the Albanian national renaissance" there were several factors at play to create that environment where different people were involved in different ways converging in their nationalist goals. Quoting from Nathalie Clayer (Clayer 2009) an Albanian student of nationalism seems to agree that there are four factors that gave birth to the Albanian nationalist movement: “... the emergence of Western Albanology, identity searching on the part of some Arberesh (Italians of Albanian descent), dissemination of Christian writings in the Albanian language from some Protestant missionaries, and the national movements of neighboring people in the Balkans” (Sulstarova 2015, 26).

It should be seen as very significant therefore, that at least two of these factors are directly related to Protestants; (1) the starting of Albanology, when according to its exponents, speaking about the first Protestant translation of the Bible in Albanian by Meksi in 1827, it is said: “... for the Albanian language the time of doubting and insecurity ended with this translation" (Lloshi 2012, 110-11), and (2) the dissemination of Christian writings in the Albanian language by Protestant missionaries. The catalytic role of the Bible, because of its dissemination and the flexibility of use by the European scholars and linguists, is the important undeniable factor in the beginning of the Albanology from J. Ksilander in 1835, and continuing with J.G. Hahn, Dh. Kamarda, G. Meyer (Lloshi 2012, 110-11).

Lloshi writes about the Protestant publication of the Bible in 1827: “... the first New Testament in the Albanian Language ... the veritable text of the written language of one of the most ancient people of the Balkans" as such that "the quest of the European scientific study of Albanian language approached it as the most valuable and reliable source" (Lloshi 2012, 108).

More correctly, it is both the translation in the Albanian language with the facilitating of alphabets and the wide dissemination of the Bible as 
well as other Protestant Christian material that the Albanian language was established in the world of letters to the point that the current version of Albanian was chosen based on this broader use enabled by Protestants (Kristoforidhi 2017, Volumi 9:49).

Discerning the typical patterns influenced by Protestant Reformation, such as the translation of the Bible and the starting of the schools in the language of the people one should not be surprised that the Albanian protestants from the beginning are found in these fronts (Quanrud 2016). As we saw with Luther, the school was integral part of the Protestant idea of making the gospel available for all people while indirectly releasing all the potential of educated humanity and fostering the national ideals.

More specifically, in the case of Albania, we have the British and Foreign Bible Society, a Protestant Evangelical organization, not accidently founded in 1804 in the middle of the Evangelical Awakenings we mentioned earlier, who was interested to bring the Bible in the Albanian language as early as 1816 (Lloshi 2012, 37). Xhevat Lloshi, a well known Albanian scholar, writes about the first person who worked tirelessly for the first Albanian publication of the Bible: " Robert Pinkerton would thus give a precious contribution for the Albanian culture, exactly that the qualities of rough Albanians to become more refined" (Lloshi 2012, 67). This makes evident that the sincere Protestant interest for the Bible was not in contradiction with the awakened national interests of the nations.

When he speaks of the decision since the establishing of the British and Foreign Bible Society to translate the Bible in the languages of different people of the world, Lloshi writes: “... from the spirit [of this decision], such a decision would need to be compared with Reformation of the XVI century itself, when Protestantism starts (Lloshi 2012, 30). This is also my argument in this presentation: Protestantism was the spirit that brought the cultivation of the national language and national education albeit because of its biblical motivation that the good news may be preached to all people.

The impact of Protestants in the formatting of the Albanian national consciousness may be difficult to measure but cannot be ignored. With the first publishing of the Bible in Albanian that became foundational for the cultivating of the written Albanian language as well as for the establishing of Albanology since 1827, continuing with the Albanian schools for girls since 1891 by Gjerasim Qiriazi and his sister, and contributing in the formation of the Albanian alphabet in Manastir in 1908 followed by Instituti Qiriazi who continued to educate the Albanian girls until all the private schools were closed in 1933 when the Albanian national education was established, we have just a few significant milestones to remember. 
This is the reason why professor Giovanni Cimbalo is very clear in his well-researched conclusion that Albanian Protestant Evangelicals are a traditional religious entity: "We have seen already that its history [Albanian Protestantism] is deeply involved with the efforts for the emancipation of the Albanian nation; reviving and broad dissemination of the Albanian language; engendering national literacy and participating in the war for independence” (Cimbalo 2013, 244).

\section{Conclusion}

Albanian Protestants were neither the only ones nor the most prominent among the many Albanian patriots in the Albanian Renaissance period, but they were a very important and appreciated factor of that formative period.

Naim Frasheri and his brother Sami, our most prominent renaissance leaders who held high offices in the Ottoman government, offered indispensable help for the writings and schools of the Albanian Protestants. Their nephew, Mid'hat Frasheri, who was minister of education and communication in the Albanian government later on was also a strong supporter of the Bible Society. He wrote in 1911:

"National sentiment... is so strong as to quiet down every difference that the diversity of religions could create. Albania has never known the bitterness of religious hate; and whatever is the creed, Catholic, Orthodox, Islamic, the Albanian is always a good patriot." Later on in a continuing writing he says: "Above all, I feel obligated to offer appropriate recognition for the contribution of the British and Foreign Bible Society, for its services toward our country and literature, through the translation of Scripture in Albanian. As a matter of fact, it is impossible to speak of the Albanian literature without mentioning the work and determination of those who for such a long time and against many difficulties have continued this noble work” (Young 2011, 48).

Another patriot, Mihal Grameno has written about the first school of girls:

"It should not be denied and never forgotten the great services that have been given to the cause [national cause] this "national nest" which was a center and a castle where gathered and were disseminated the national ideas as sparks. This "nest" was the school of girls in Korca, established by the undying national apostle Gjerasim D. Qirias, whose name, the history of Albania will write with golden letters, boasting with his works and invaluable services that he brought to the fatherland's altar" (Kuanrud 1998, 166).

As we tried to show here, historically, Protestantism liberated the free thinking and the rule of conscience establishing the role of the authority of the text encouraging critical thinking and self-governing choice. From 
Luther’s Germany, this movement spread far and wide arriving in Albania as well in the form of Evangelicalism with the first publishing of the Bible in 1827 in the Albanian language. Since that beginning, and especially with the Albanian national awakening, we see the role of Protestant Evangelicals in helping with the foundations of the written language and establishing of the Albanian national education thus establishing their work as an integral part of the Albanian nation and is rightly recognized as a traditional religious community.

\section{References:}

1. Brinton, Crane. 1963. The Shaping of Modern Thought. Englewood Cliffs, New Jersey: Prentice-Hall, Inc.

2. Cimbalo, Giovanni. 2013. Pluralizmi i besimit dhe komunitetet fetare ne Shqiperi. Studime te se drejtes se krahasuar. E drejta kishtare dhe te drejtat njerezore. Tirana, Albania: Naimi.

3. Clayer, Nathalie. 2009. "Ne Fillimet E Nacionalizmit Shqiptar: Lindja E Nje Kombi Me Shumice Mysliymane Ne Evrope.” Perpjekja.

4. Guibernau, Montserrat, and John Hutchinson, eds. 2001. Understanding Nationalism. Cambridge CB2 1UR, UK: Polity Press.

5. Harrison, John B., and Richard E. Sullivan. 1980. A Short History of Western Civilization to 1776. Fifth edition. Vol. One. New York,: Alfred A. Knopf.

6. Hastings, Adrian. 1997. The Construction of Nationhood: Ethnicity, Religion and Nationalism. Cambridge: Cambridge University Press.

7. Hutchinson, John, and Anthony D. Smith. 1994. Nationalism. Oxford: Oxford University Press.

8. Kristoforidhi, Konstandin. 2017. Shkrime Dhe Perkthime. Historia E Shkrimit Te Shenjte (1870 E 1872). Kater Katekizma (1867 E 1872). Prepared for Publication by Xhevat Lloshi. Vol. Volumi 9. Seria Perkujtimore 500/200. Tirana, Albania: Institute for Albanian and Protestant Studies.

9. Kuanrud, Xhon. 1998. Bese, Shprese Dhe Dashuri. Jeta E Gjerasim Qiriazit. Tirana, Albania: Karte e Pende.

10. Latourette, Kenneth Scott. 1975. A History of Christianity. Reformation to the Present. Revised Edition. Vol. 2. New York, N.Y.: Prince Press.

11. Leoussi, Athena S., and Steven Grosby. 2007. Nationalism and Ethnosymbolism. History, Culture and Ethnicity in the Formation of Nations. Edingurgh: Edingurgh University Press.

12. Lloshi, Xhevat. 2012. Perkthimi I V. Meksit Dhe Redaktimi I G. GJirokastritit 1810-1827. Tirana, Albania: Onufri. 
13. Ozkirimli, Umut. 2010. Theories of Nationalism. A Critical Introduction. Second Edition. Hampshire RG21 6XS: Palgrave Macmillan.

14. Quanrud, John. 2016. Gerasim Kyrias and the Albanian National Awakening 1858-1894. Tirana, Albania: Institute for Albanian and Protestant Studies.

15. Reid, Patrick V. 1995. Readings in Western Religious Tought. II. The Middle Ages through the Reformation. Vol. 2. New York/Mahwah NJ: Paulist Press.

16. Sheldon, Henry C. 1994. History of the Christian Church. The Modern Church. Part One. Vol. 3. 5 vols. New York,: Thomas Y. Crowell and Co.

17. Smith, Anthony D. 1991. National Identity. Ethnonationalism in Comparative Perspective. Reno, Nevada 89557 USA: University of Nevada Press.

18. Sulstarova, Enis. 2015. Ligjerimi Nacionalist Ne Shqiperi Dhe Studime Te Tjera. Botimi i dyte. Tirana, Albania: Pika pa Siperfaqe.

19. Young, David. 2011. Levizja Protestate Midis Shqiptareve 1908 1991. Prishtine, Kosova: Tenda. 